I.А. Кулик, М.С. Шевченко

Сумський державний університет, Суми

\title{
РОЗРОБКА ІНФОРМАЦІЙНО-КЕРУЮЧИХ СИСТЕМ НА ОСНОВІ ДВІЙКОВОЇ БІНОМІАЛЬНОЇ СИСТЕМИ ЧИСЛЕННЯ
}

У статті пропонується до розгляду концепџія розробки інформаџійно-керуючих систем на основі біноміальних систем числення, в основі якої лежить нова інформачійна технологія обробки даних на базі біноміальних чисел. В рамках даної технологї проводиться формування кодових об'єктів біноміальної структури, їх перетворення в двійкові біноміальні числа $і$ зворотне перетворення результуючих кодових об'єктів у вихідні дані на основі двійкової системи числення. Наведені підходи до вирішення типових інформаційних задач з використанням біноміальних чисел.

Ключові слова: продуктивність, двійкові біноміальні числа, біноміальні перетворення.

\section{Вступ}

Постановка проблеми. В інформаційнокеруючих системах однією $з$ найпоширеніших форм представлення інформації є числова. Обробка даних проводиться на основі математичних операцій над числами, а також за допомогою обчислювальних функцій, областями визначення і значень яких є числові множини. Текстові, графічні та звукові дані в комп'ютерних системах і компонентах можна також представити у вигляді числової інформації.

Кодове подання чисел визначається використовуваною системою числення. Системи числення повинні вирішувати наступні завдання: представлення кількостей різних елементів або об'єктів, що містяться в тих чи інших множинах; упорядкування елементів або об'єктів та виконання арифметичних операцій над числами [1-3].

Всі ці завдання досить ефективно вирішують позиційні системи числення, найпростішими з яких $€$ однорідні системи. Але застосування однорідних систем числення, зокрема поширеної двійкової, не завжди може задовольнити підвищені вимоги до продуктивності сучасних комп'ютерних систем без зниження відмовостійкості їх функціонування в режимі реального часу при мінімальних додаткових апаратно-програмних витратах. Важливим напрямком подальшого розвитку комп'ютерних засобів $\epsilon$ використання для подання та обробки даних структурних систем числення [4-6]. При цьому структурні числові системи можуть або повністю задавати всі процеси функціонування комп'ютерних систем i компонентів, або бути задіяні локально в структурі ïx апаратного або програмного забезпечення для вирішення окремих інформаційних завдань, наприклад завдань комбінаторної оптимізації, шифрування або стиснення інформаційних послідовностей.

Як відомо [4-6], характерною особливістю структурних систем числення є те, що вага цифр структурного числа визначається їх залежністю не тільки від позиції в самому числі, але і від значень попередніх їм цифр. Такий зв'язок ускладнює визначення кількісних еквівалентів структурних чисел i, власне, саму арифметику систем числення. Але призводить до виникнення у структурних систем чисел важливих позитивних властивостей, таких як здатність перераховувати і генерувати складні комбінаторні об'єкти, виявляти і виправляти помилки.

Структурні системи числення відображають структури впорядкованої множини елементів. Урахування цього фактору дає можливість розробляти методи перетворення та кодування на базі загального підходу, який полягає у використанні єдиного набору стандартних кроків [4; 6]:

1) виявлення структурних особливостей множини кодованих елементів;

2) побудова відповідної до множини структурної системи числення;

3) зіставлення кожному елементу кодової множини відповідного структурного числа.

У даній науковій роботі буде розглядатися концепція розробки спеціалізованих інформаційнокеруючих систем на основі структурних біноміальних систем числення $з$ двійковим алфавітом і основи нової інформаційної технології по перетворенню і кодуванню інформації з використанням двійкових біноміальних чисел [4-6]. Двійкова біноміальна система числення має особливі перспективи 3 точки зору простоти алгоритмів формування біноміальних чисел і розширення сфери ії застосування для різних типів інформаційних послідовностей.

Аналіз останніх досліджень і публікацій. Використання систем числення, відмінних від традиційної двійкової системи чисел, для побудови спеціалізованих інформаційно-керуючих систем і обчислювальних засобів, а також вирішення спеціалізованих завдань в рамках універсальних комп'ютерних систем і компонентів $€$ ефективним і перспективним напрямком [7-8]. 
У роботах [9-11] розглядається застосування чисел Фібоначчі для побудови самоконтролюючих і самокорегуючих обчислювальних і вимірювальних систем, яке є відображенням цілого “фібоначчійового” напряму по створенню комп'ютерної та вимірювальної техніки. Біноміальні числа, хоча і є складніше чисел (кодів) Фібоначчі, але мають помітно більшу завадостійкість, більший потенціал до виявлення і виправлення помилок. Відповідно, рівень перешкодозахищеності і відмовостійкості інформаційно-керуючих систем і спеціалізованих пристроїв на основі двійкових біноміальних чисел буде безумовно вище. Крім того, біноміальні числа мають дуже корисну здатність генерувати широкий спектр комбінаторних об'єктів.

У роботах [12-14] наводяться методи обробки даних і концепція побудови систем обробки інформації на основі використання систем залишкових класів. Системи залишкових класів є непозиційними системами чисел 3 паралельною структурою, що дозволяє розпаралелювати операції на рівні виконання елементарних арифметичних команд. Залишкові класи в основному обмежені застосуванням для вирішення ряду спеціалізованих завдань над цілочисельними даними: контроль і діагностика помилок в цифрових системах обробки сигналів, високошвидкісна обробка цілих чисел, захист інформації. Недоліками інформаційно-керуючих систем на основі систем залишкових класів $є$ істотні труднощі в сполученні з системами обробки інформації на позиційних системах чисел, наприклад поширеної двійкової, відсутність ефективних алгоритмів порівняння чисел, значна трудомісткість немодульних операцій. Біноміальні числа $є$ числами зі складною структурою, але все ж відносяться до позиційних чисел. Відповідно, така “позиційність” визначає значно простіші й ефективніші алгоритми переходу від чисел біноміальної системи числення до двійкових чисел, порівняння біноміальних чисел між собою і повне виключення з розгляду модульності або немодульності арифметичних операцій.

В роботі [15], в основі якої лежать авторські свідоцтва та патенти на винаходи, вже зроблено досить серйозний внесок в розробку біноміальних пристроїв і компонентів, які можуть бути складовими будь-яких інформаційно-керуючих систем на основі двійкових біноміальних чисел.

Мета статті - підвищення продуктивності обробки даних в інформаційно-керуючих системах, комп'ютерних системах і компонентах при мінімальних додаткових апаратно-програмних витратах 3 точки зору підвищення відмовостійкості та надійності апаратури і програмного забезпечення, швидкодії і завадостійкості вирішення завдань генерування і перерахування комбінаторних об'єктів, комбінаторної оптимізації, стиснення і передачі інформації.
Засобами досягнення зазначеної мети є розробка нової інформаційної технології обробки даних на основі двійкових біноміальних чисел і ії реалізація в біноміальних інформаційно-керуючих системах i пристроях, а також в універсальних комп'ютерних системах та компонентах для вирішення відповідних спеціалізованих завдань.

Областю призначення наукових і практичних результатів роботи $є$ як комп'ютерні системи універсального характеру, так і спеціалізовані пристрої, призначені для вирішення інформаційних завдань за допомогою двійкових біноміальних чисел.

\section{Виклад основного матеріалу}

\section{Основи розробки систем на основі двійкових біноміальних чисел}

У комп'ютерних засобах i компонентах, що складають основу сучасних інформаційно-керуючих систем, для збільшення продуктивності обробки інформації без зниження відмовостійкості при мінімальних витратах, пропонується здійснювати кодування і перетворення даних на основі структурних біноміальних чисел, які генеруються біноміальними системами числення з двійковим алфавітом.

Обмеження на біноміальні числа, породжувані біноміальною системою числення, зумовлюють структуру кодованих і перетворених множин інформаційних послідовностей. Поставивши у відповідність вихідним комбінаціям кодованих множин біноміальні числа, можна домогтися більш економного їх подання, можливості виявляти і виправляти помилки, здатності проводити над ними різні види обчислювальних операцій.

Першою ідейною основою теоретичного i практичного матеріалу щодо побудови інформаційно-керуючих систем на основі двійкових біноміальних чисел $є$ те, що в структурі упорядкованої кодованої і перетворюваної множини можна виділити відповідну їй двійкову біноміальну систему числення, а кодовим послідовностям такої множини поставити у взаємно однозначну відповідність структурні біноміальні числа $[4 ; 6]$.

Іншим напрямком в кодуванні і перетворенні інформації $є$ застосування біноміальної числової функції, що дозволяє отримати номери інформаційних послідовностей. Застосовуваний структурний підхід для отримання номерів полягає в тому, що спочатку за допомогою двійкової біноміальної системи числення знаходяться біноміальні числа, що лежать в основі кодованих послідовностей, а потім від двійкових біноміальних чисел проводиться перехід безпосередньо до самих номерів [4; 6].

Таким чином, другою ідейною основою використання двійкових біноміальних чисел є те, що 3 процесу вирішення завдань нумераційного кодуван- 
ня виділяється окремий етап формування біноміальних чисел, що призводить, з одного боку, до універсалізації самого завдання біноміальної нумерації, а 3 іншого, до зниження апаратно-програмних і часових витрат при її практичної реалізації.

Сполучною ланкою представлених підходів до підвищення продуктивності інформаційно-керуючих систем при досягненні необхідного рівня відмовостійкості та надійності є розробка машинної арифметики для біноміальних чисел, за допомогою яких подається інформація в комп'ютерних засобах. 3 одного боку, вона реалізує цілісність і функціональну повноту математичного (і алгоритмічного) забезпечення інформаційно-керуючих систем на основі біноміальних систем числення, а $з$ іншого - формує основу для подальшого збільшення їх продуктивності за рахунок нових перспективних методів біноміальних кодування і перетворення даних.

В рамках трьох взаємопов'язаних наукових напрямків, а саме:

1) генерування математичних об'єктів - комбінаторних конфігурацій (кодів) - на структурі упорядкованих множин двійкових біноміальних чисел;

2) перерахування математичних об'єктів комбінаторних конфігурацій (кодів) - за допомогою двійкових біноміальних систем числення і генеруючих ними біноміальних чисел;

3) розробка машинної біноміальної арифметики для біноміальних чисел, які генеруються двійковими біноміальними системами числення;

в основі яких лежить структурний підхід до подання, перетворення і кодування двійкової інформації в режимі реального часу, пропонується розробка нової інформаційної технології по обробці даних на основі двійкових біноміальних чисел. В якості комбінаторних конфігурацій пропонується розглядати коди з постійною вагою, або рівноважні комбінації, квазірівноважні комбінації та інші коди-сполучення [16], які мають досить широке поширення, а також які легко можна виділити простим підрахунком чисел одиниць або нулів в послідовностях з інформаційного масиву загального вигляду.

На рис. 1 наведена концепція розробки інформаційно-керуючої системи, що використовує двійкову біноміальну систему числення, яка, на відміну від існуючих моделей інформаційної технології 3 побудови інформаційно-керуючих систем на традиційній двійковій системі числення, включає в себе нові послідовно виконуючі етапи по перетворенню і кодуванню інформації з метою вирішення типових інформаційних завдань:

1) при організації та підготовці двійкових даних для введення в інформаційно-керуючу систему формуються на їх основі взаємно однозначні кодові об'єкти біноміальної структури;
2) одержувані кодові об'єкти перетворюються в структурні двійкові біноміальні числа для реалізації типових інформаційних процесів інформаційнокеруючої системи;

3) при виведенні і поданні результуючої інформації споживачам інформаційно-керуючої системи здійснюється зворотне перетворення двійкових біноміальних чисел або відповідних їм кодових об'єктів біноміальної структури в вихідні дані на основі двійкової системи числення.

\section{Практичні аспекти впровадження двійкових біноміальних чисел}

\section{Двійкові $(n, k)$-біноміальні числа} $X_{j}=x_{1} x_{2} \ldots x_{i} \ldots x_{r}$ з множини $X[n, k], X_{j} \in X[n, k]$, повинні задовольняти системам кодоутворюючих обмежень:

$$
\left\{\begin{array} { l } 
{ l = n - k } \\
{ x _ { r } = 0 }
\end{array} \text { i } \left\{\begin{array}{l}
q=k \\
x_{r}=1
\end{array},\right.\right.
$$

які є наслідком з числової функції $(n, k)$-біноміальної системи числення:

$$
F_{j}=\operatorname{dec} X_{j}=\sum_{i=1}^{r} x_{i} C_{n-i}^{k-q_{i}}
$$

де $n$ і $k$ - параметри $(n, k)$-біноміальної системи числення, $q$ і $l$ - кількості двійкових одиниць і нулів в двійковому $(n, k)$-біноміальному числі $X_{j}$, а $q_{i}=\sum_{t=1}^{i-1} x_{t}-$ сума одиничних цифр $x_{i}$ від першого розряду до $(i-1)$-го включно.

Вирішити завдання передачі і зберігання даних в інформаційно-керуючих системах можна $з$ успіхом, застосовуючи двійкові $(n, k)$-біноміальні числа $X_{j}$ і методи стиску на їх основі [17-18]. При цьому використовуються наступні властивості і особливості біноміальних чисел $X_{j}$ :

1) довжина $r$ для чисел $X_{j}$ змінюється в межах $\min (k, n-k) \leq r \leq n-1$ і може бути значно меншою, ніж кількість $n$ розрядів перетворених кодових послідовностей $A_{j}$, де $A_{j} \in\{0,1\}^{n}$;

2) виконується властивість префіксності для біноміальних чисел $X_{j}$;

3) здійснюються досить прості кодові перетворення послідовностей $A_{j}$ в біноміальні числа $X_{j}$ i навпаки

Таким чином, будується взаємно-однозначне відображення такого вигляду $f_{b}: Y[n, k] \rightarrow X[n, k]$, де 


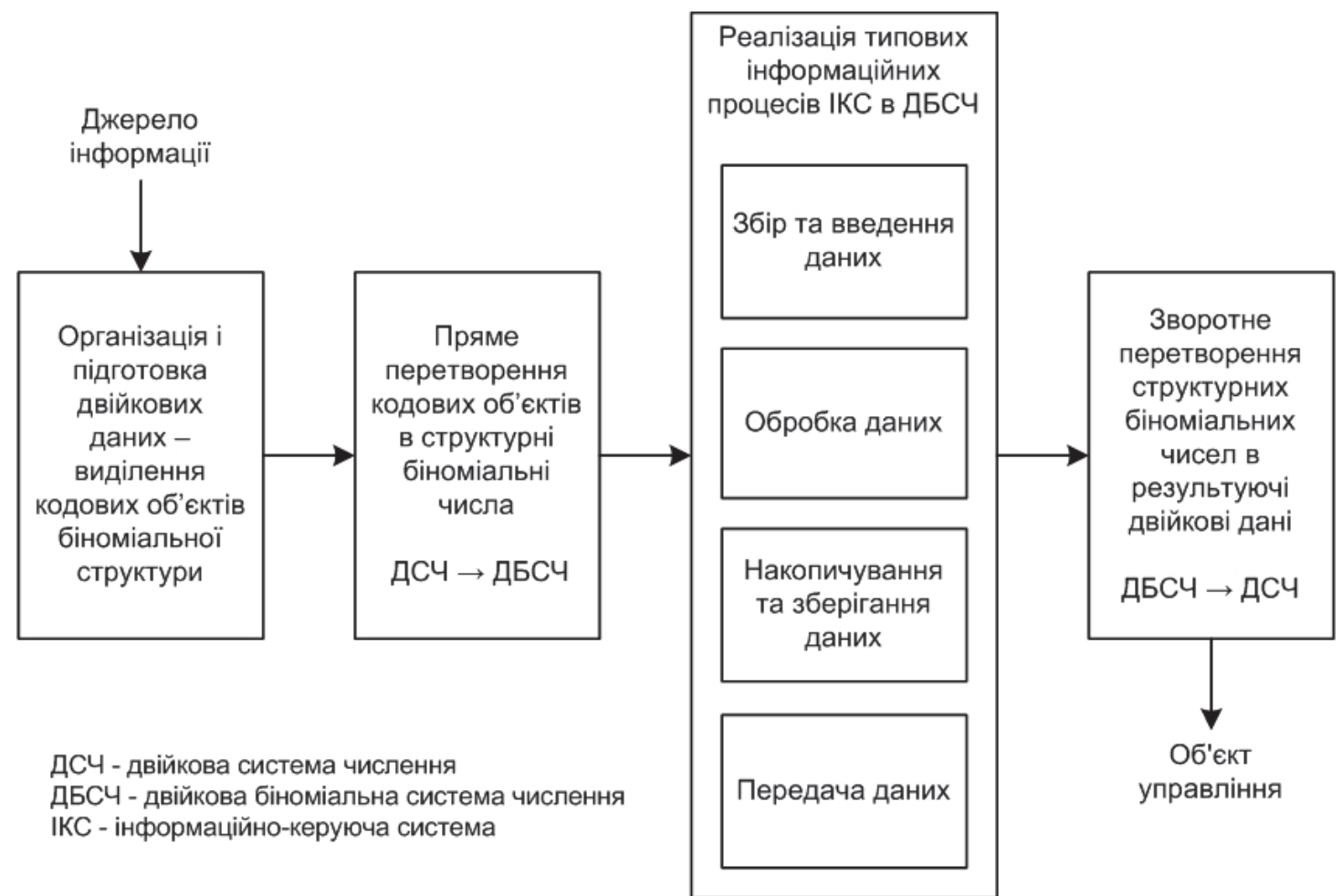

Рис. 1. Концепція розробки інформаційно-управляючої системи, що використовує двійкову біноміальну систему чисел (опрацьовано автором)

$Y[n, k]$ - множина $n$-розрядних рівноважних комбінацій $Y_{j}$, що мають число $k$ двійкових одиниць і

$$
A=\bigcup_{k=0}^{n} Y[n, k] .
$$

При необхідності ще більшого підвищення продуктивності інформаційно-керуючих систем i достатності часових ресурсів слід перейти до методів стиснення і відновлення двійкової інформації на основі біноміальної числової функції (2). В цьому випадку кожній інформаційної послідовності $A_{j}$ ставиться у відповідність двійковий номер $D_{j}=\operatorname{Bin} F_{j}$, а двійкові $(n, k)$-біноміальні числа $X_{j}$ використовуються як проміжна ланка в даних перетвореннях. Тоді реалізується взаємнооднозначне відображення вигляду $f_{e}: Y[n, k] \rightarrow D$, де $D$ - множина двійкових номерів $D_{j}$. Перехід від інформаційної послідовності $A_{j} \in A$ до відповідної рівноважної комбінації $Y_{j}$ здійснюється шляхом простого підрахунку $k$ одиниць в $A_{j}$, тобто виконується взаємно-однозначне відображення $f_{w}: A_{j} \rightarrow\left(k, Y_{j}\right)$ послідовності $A_{j}$ в впорядковану пару $\left(k, Y_{j}\right)$, де $Y_{j}=A_{j}$.

Складні функції, що забезпечують запропоно- ване стиснення двійкових даних, мають такий вигляд:

1) для методу $f_{b c}$ на основі двійкових біноміальних чисел:

$$
f_{b c}=f_{k} \circ f_{b} \circ f_{w}
$$

2) для методу $f_{b e}$ на основі біноміальної числової функції:

$$
f_{b e}=f_{k} \circ f_{e} \circ f_{b} \circ f_{w},
$$

де $f_{k}$ - кодування, яке ставить у відповідність стиснуті образи і двійкові значення $\operatorname{Bin} k$ вихідних інформаційних послідовностей $A_{j}$. Слова $\operatorname{Bin} k$ необхідні для однозначного відновлення $A_{j}$ за допомогою зворотних функцій $f_{b c}^{-1}$ i $f_{b e}^{-1}$.

Використання двійкових $(n, k)$-біноміальних чисел дає можливість підвищити продуктивність інформаційно-керуючих систем за рахунок збільшення швидкості обміну даних між підсистемами і зовнішніми пристроями, зменшити час доступу до пам'яті та підвищити швидкість виконання запитів, наприклад до баз даних або в розподілених системах автоматизації керування процесами [19-20].

Разом $з$ економним поданням інформації, організацією передачі і зберігання даних двійкові $(n, k)$ біноміальні числа дозволяють також вирішувати завдання забезпечення відмовостійкості роботи систем і блоків, а також завадостійкості передачі даних 
між ними. Системи кодоутворюючих обмежень (1) надають механізми контролю правильності кодових комбінацій, які відображають біноміальні числа, i безпомилковості функціонування пристроїв і блоків на їх основі. Двійкові $(n, k)$-біноміальні числа в разі правильності їх представлення повинні відповідати таким вимогам:

1) кількість одиниць $0 \leq q \leq k-1$ та нулів $l=n-k$, або $q=k$ та $0 \leq l \leq n-k-1$, для нерівномірних кодових комбінацій;

2) кількість одиниць $0 \leq q \leq k-1$ та нулів $l=2 n-k-r$, або $q=k$ та $n-r \leq l \leq 2 n-k-r-1$, для рівномірних кодових комбінацій.

Таким чином, можливе виявлення і виправлення певної частини помилок при передачі двійкових $(n, k)$-біноміальних чисел по каналам зв'язку або при їх зберіганні в пам'яті. Крім того, можлива організація контролю правильності роботи та самодіагностика цифрових компонентів і вузлів, що функціонують на двійкових біноміальних кодах (числах), наприклад біноміальних лічильників, шифраторів і дешифраторів [15].

Як вже зазначалося [4;6], біноміальні числа можна виділити в структурі множини комбінаторних об'єктів, що призводить до можливості їх використання для генерування і перерахування комбінаторних конфігурацій з метою вирішення різних завдань комбінаторної оптимізації. Очевидно, що такий підхід у разі тотожності їх структурних властивостей буде характеризуватися істотно меншими апаратно-програмними і часовими витратами, ніж у разі використання двійкової системи числення. В інформаційно-керуючих системах широкого поширення набули рівноважні та квазірівноважні коди, інші коди-сполучення, у яких кількості одиниць (нулів) або відстані між ними в розрядній сітці підкоряються певним обмеженням [16;21].

Моделі перерахування і генерування кодівсполучень як складових процесів біноміального перетворення даних в інформаційно-керуючих системах представляються складними функціями наступного вигляду [21]:

1) перечислення кодів-сполучень $Y_{j}\left[R_{Y}\right]$ с заданим обмеженням $R_{Y}$ з метою отримання їх номерів $F_{j}-$

$$
F_{j}=f\left(Y_{j}\left[R_{Y}\right]\right)=\psi\left(\varphi^{-1}\left(Y_{j}\left[R_{Y}\right]\right)\right) ;
$$

2) генерування кодів-сполучень $Y_{j}\left[R_{Y}\right]$ с заданим обмеженням $R_{Y}$ на основі відповідних номерів $F_{j}-$

$$
Y_{j}\left[R_{Y}\right]=f^{-1}\left(F_{j}\right)=\varphi\left(\psi^{-1}\left(F_{j}\right)\right),
$$

де $\psi: X \rightarrow F$ i $\psi^{-1}: F \rightarrow X-$ бієктівні біноміальні пряме і зворотне відображення множини $X$ біноміальних чисел $X_{j}$ на множину $F$ номерів $F_{j}$ і зворотне $F$ на $X$ відповідно. Відображення $\psi$ і $\psi^{-1}$ реалізуються 3 використанням наведеної біноміальної числової функції (2) і систем кодоутворюючих обмежень (1).

У зв'язку з цим слід зазначити генерування i перерахування квазірівноважних комбінацій на основі двійкових $(n, k)$-біноміальних чисел на основі співвідношень (3) і (4) [22-23]. Квазірівноважні $n$ розрядні комбінації з числами $k \mathrm{i}(k-1)$ одиниць хоча і поступаються трохи по здатності виявлення помилок рівноважним кодам $з$ параметрами $n$ i $k$, але мають значно більшу інформаційну потужність кодових множин. Квазірівноважні коди мають серйозну перспективу для побудови t-EC/AUED кодів, здатних виявляти і виправляти як симетричні, так i несиметричні помилки [24].

Практична реалізація біноміальної машинної арифметики, тобто арифметики двійкових біноміальних чисел, послужить основою ще більшого поширення біноміальних чисел та інформаційнокеруючих систем, побудованих на їх основі. В роботі [25] виражений підхід, в якому вагові коефіцієнти $C_{n-i}^{k-q_{i}}(2)$ представляються як кортежі $\left(\alpha_{i}, \Delta_{i}\right)$ верхнього $\alpha_{i}=k-q_{i}$ і нижнього параметрів $\beta_{i}=n-i$, де $\Delta_{i}=\beta_{i}-\alpha_{i}$, а самі двійкові біноміальні числа як сукупності $S_{j}$ кортежів $\left(\alpha_{i}, \Delta_{i}\right)$. В цьому випадку дії над двійковими біноміальними числами $X_{1}$ i $X_{2}$ зводяться до операцій над параметрами $\alpha_{i}$ i $\beta_{i}$ відповідних сукупностей $S_{1}$ i $S_{2}$.

\section{Висновки}

Розробка нової інформаційної технології по обробці даних на основі двійкових біноміальних чисел розкриває широкі можливості щодо підвищення продуктивності спеціалізованих інформаційнокеруючих систем, ефективності вирішення окремих інформаційних завдань в універсальних комп'ютерних системах і компонентах з точки зору збільшення швидкодії, збереження відмовостійкості та надійності передачі при мінімумі апаратно програмних витрат.

Істотні переваги біноміальні числа і генеруючі ïх біноміальні системи числення мають при перетвореннях і обробці кодових послідовностей, що мають подібні структурні властивості, наприклад рівноважних і квазірівноважних комбінацій, кодівсполучень.

До числа інформаційних завдань, для вирішен- 
ня яких успішно використовуються двійкові біноміальні числа, відносять забезпечення відмовостійкості і самодіагностики біноміальних пристроїв і систем, завадостійку передачу біноміальних кодів, біноміальне адаптивне стиснення двійкової інформації, генерування різних комбінаторних конфігурацій.
Перспективними є застосування двійкових біноміальних чисел і генеруючих їх біноміальних систем числення для вирішення комбінаторних задач оптимізації та впровадження біноміальної машинної арифметики.

\section{Список літератури}

1. Поспелов Д.А. Арифметические основы вычислительных машин дискретного действия / Д.А. Поспелов. - М.: Высшая школа, 1970. - 308 с.

2. Кнут Д.Э. Искусство программирования, т. 2. Получисленные алгоритмы / Д.Э. Кнут. - М.: ООО “И.Д. Вильямс", 2018. - 832 с.

3. Гашков С.Б. Системы счисления и их применение / С.Б. Гашков. - М.: Изд-во МЦНМО, 2004. - 52 с.

4. Борисенко А.А. Биномиальное кодирование: монография / А.А. Борисенко, И.А. Кулик. - Сумы: Изд-во СумГУ, 2010. $-206 \mathrm{c}$.

5. Борисенко А.А. Введение в теорию биномиального счета: монография / А.А. Борисенко. - Сумы: ИТД “Университетская книга", 2004. - 88 с.

6. Борисенко А.А. Биномиальный счет. Теория и практика: монография / А.А. Борисенко. - Сумы: ИТд "Университетская книга", 2004. - 170 с.

7. Stakhov A. A History, the Main Mathematical Results and Applications for the Mathematics of Harmony / A. Stakhov // Applied Mathematics. - 2014. - Vol. 5, No. 3. - P. 363-386. https://doi.org/10.4236/am.2014.53039.

8. Effective Data Processing in Coding, Digital Signals and Cryptography: monograph / V. Krasnobaev, A. Kuznetsov, S. Rassomakhin, A. Zamula, S. Koshman, S. Kavun. - Minden, Nevada, USA: ASC Academic Publishing, 2018. - 352 p.

9. Stakhov A. The 'Golden' Matrices and a New Kind of Cryptography / A. Stakhov // Chaos, Solitons \& Fractals. - 2007. - Vol. 32, No. 3. - P. 1138-1146. http://dx.doi.org/10.1016/j.chaos.2006.03.069.

10. Esmaeili M. A new class of Fibonacci sequence based error correcting codes / M. Esmaeili, M. Moosavi, T.A. Gulliver // Cryptogr. Commun. - 2017. - 9. - P. 379-396. https://doi.org/10.1007/s12095-015-0178-x.

11. Stankovic' S. Radomir. Circuit Synthesis from Fibonacci Decision Diagrams / Radomir S. Stankovic', Jaakko Astola, Milena Stankovic', Karen Egiazarian // VLSI Design. - 2002. - Vol. 14(1). - P. 23-34. https://doi.org/10.1080/ 10655140290009783.

12. Модели и методы обработки данных в системе остаточных классов: монография / С.А. Кошман, В.А. Краснобаев, С.А. Мороз, В.Н. Курчанов, А.С. Янко. - Харьков: ООО “В деле”, 2017. - 197 с.

13. Mohan P.V.A. Applications of Residue Number Systems. In: Residue Number Systems / P.V.A. Mohan. - The Springer International Series in Engineering and Computer Science Springer (SECS, vol. 677), Boston, MA, 2002. - P. $199-234$. https://doi.org/10.1007/978-1-4615-0997-4_8.

14. Krasnobayev V.A. A Method for Arithmetic Comparison of Data Represented in a Residue Number System / V.A. Krasnobayev, A.S. Yanko, S.A. Koshman // Cybern Syst Anal. - 2016. - № 52. - P. $145-150$. https://doi.org/10.1007/s10559-016-9809-2. $152 \mathrm{c}$.

15. Борисенко А.А. Биномиальный счет и счетчики: монография / А.А. Борисенко. - Сумы: Изд-во СумГУ, 2008. -

16. Амелькин В.А. Перечислительные задачи серийных последовательностей / В.А. Амелькин. - Новосибирск: ИВМиМГ СО РАН, 2008. - 317 с.

17. Кулик И.А. Метод оценки границ применения сжатия на основе двоичных биномиальных чисел / И.А. Кулик, А.И. Новгородцев, М.С. Шевченко // Системи обробки інформації. - 2019. - № 2(157). - С. 57-62. https://doi.org/ 10.30748/soi.2019.157.07.

18. Kulyk I. Development of data compressing coding methods on basis of binary binomial numbers / I. Kulyk, O. Berezhna, M. Shevchenko // Technology Audit and Production Reserves. - 2019. - № 2/2(46) - P. 12-18. https://doi.org/10.15587/ 2312-8372.2019.169897.

19. Кулик И.А. Биномиальная модель векторного представления базы данных с колоночной структурой / И.А. Кулик, А.И. Новгородцев, Е.М. Скордина // Системи обробки інформації. - 2016. - № 4(141). - С. 50-56.

20. Смирнов М.А. Обзор применения методов безущербного сжатия данных в СУБД [Електронний ресурс] / М.А. Смирнов. Санкт-Петербург: Санкт-Петербургский государственный университет аэрокосмического приборостроения, 2004. - 58 с. Режим доступу: http://compression.ru/download/articles/db/smirnov_2003_database_compression_review.pdf.

21. Кулик И.А. Генерирование кодов-сочетаний для решения информационных задач ИУС / И.А. Кулик, Е.М. Скордина, С.В. Костель // АСУ и приборы автоматики. Всеукраинский межведомственный сборник. - 2011. № 155 . - С. 15-23.

22. Обобщенные вероятности необнаруживаемой ошибки для квазиравновесных кодов / И.А. Кулик, А.И. Новгородцев, Е.М. Скордина, В.В. Арбузов // Системи обробки інформації. - 2014. - № 9(125). - С. 43-49. 
23. Кулик И.А. Формирование квазиравновесных кодов на основе двоичных биномиальных чисел / И.А. Кулик, Е.М. Скордина, С.В. Костель // Вісник Сумського державного університету. Серія Технічні науки. - 2010. - № 1. C. $134-142$.

24. Kohzuki K. A Class of Single Error Correcting Constant Weight Codes / K. Kohzuki, K. Tokiwa, H. Tanaka // Electronics and Communications in Japan. - Part 3. - 1997. - Vol. 80. - No. 7. - P. 55-64. https://doi.org/10.1002/(SICI)15206440(199707)80:7<55::AID-ECJC7>3.0.CO;2-0.

25. Кулик И.А. К вопросу о сложении биномиальных чисел / И.А. Кулик // Вісник Сумського державного університету. Серія Технічні науки. - 2012. - № 3. - С. 101-109.

\section{References}

1. Pospelov, D.A. (1970), "Arifmeticheskie osnovy vychislitel'nyh mashin diskretnogo dejstvija" [The arithmetic foundations of discrete operation computing machinery], Vysshaja shkola, Moscow, 308 p.

2. Knut, D.Je. (2018), "Iskusstvo programmirovanija, t. 2. Poluchislennye algoritmy" [The art of computer programming, V. 2, Seminumerical Algorithms], OOO “I.D. Vil'jams”, Moscow, 832 p.

3. Gashkov, S.B. (2004), "Sistemy schislenija i ih primenenie" [Number systems and their application], Izd-vo MCNMO, Moscow, $52 \mathrm{p}$.

4. Borysenko, A.A. and Kulyk, I.A. (2010), “Binomial'noe kodirovanie: monografija” [Binomial coding], Sumy State University, Sumy, $206 \mathrm{p}$.

5. Borysenko, A.A. (2004), "Vvedenie v teoriju binomial'nogo scheta: monografija" [Intoduction into binomial count], ITD "Universitetskaja kniga", Sumy, 88 p.

6. Borysenko, A.A. (2004), "Binomial'nyj schet. Teorija i praktika: monografija" [Binomial count. Theory and practice], ITD "Universitetskaja kniga”, Sumy, $170 \mathrm{p}$.

7. Stakhov, A. (2014), A History, the Main Mathematical Results and Applications for the Mathematics of Harmony, Applied Mathematics, Vol. 5, No. 3, pp. 363-386. https://doi.org/10.4236/am.2014.53039.

8. Krasnobaev, V., Kuznetsov, A., Rassomakhin, S., Zamula, A., Koshman, S. and Kavun, S. (2018), Effective Data Processing in Coding, Digital Signals and Cryptography: monograph, ASC Academic Publishing, Minden, Nevada, USA, 352 p.

9. Stakhov, A. (2007), The 'Golden' Matrices and a New Kind of Cryptography, Chaos, Solitons \& Fractals, Vol. 32, No. 3, pp. 1138-1146. http://dx.doi.org/10.1016/j.chaos.2006.03.069.

10. Esmaeili, M., Moosavi, M. and Gulliver, T.A. (2017), A new class of Fibonacci sequence based error correcting codes, Cryptogr. Commun., No. 9, pp. 379-396. https://doi.org/10.1007/s12095-015-0178-x.

11. Stankovic', S.R., Astola, Ja., Stankovic', M. and Egiazarian, K. (2002), Circuit Synthesis from Fibonacci Decision Diagrams, VLSI Design, Vol. 14 (1), pp. 23-34. https://doi.org/10.1080/10655140290009783.

12. Koshman, S.A., Krasnobaev, V.A., Moroz, S.A., Kurchanov, V.N. and Janko, A.S. (2017), "Modeli i metody obrabotki dannyh $v$ sisteme ostatochnyh klassov: monografija" [Models and methods of data processing in a system of residual classes], OOO "V dele", Kharkiv, 197 p.

13. Mohan, P.V.A. (2002), Applications of Residue Number Systems, Residue Number Systems, The Springer International Series in Engineering and Computer Science Springer (SECS, Vol. 677), Boston, MA, pp. $199-234$. https://doi.org/10.1007/978-1-4615-0997-4_8.

14. Krasnobayev, V.A., Yanko, A.S. and Koshman, S.A. (2016), Method for Arithmetic Comparison of Data Represented in a Residue Number System, Cybern Syst Anal., No. 52, pp. 145-150. https://doi.org/10.1007/s10559-016-9809-2.

15. Borysenko, A.A. (2008), "Binomial'nyj schet i schetchiki: monografija" [Binomial count and counters], Izd-vo SumGU, Sumy, $152 \mathrm{p}$.

16. Amelkin, V.A. (2008), "Perechislitelnye zadachi serijnyh posledovatelnostej" [Emumeration problems of serial sequences], IVMiMG SO RAN, Novosibirsk, 317 p.

17. Kulyk, I.A., Novhorodtsev, A.I. and Shevchenko, M.S. (2019), "Metod ocenki granic primenenija szhatija na osnove dvoichnyh binomial'nyh chisel" [Method for borders estimation of compression on basis of binary binomial numbers], Information Processing Systems, No. 2(157), pp. 57-62. https://doi.org/ 10.30748/soi.2019.157.07.

18. Kulyk, I., Berezhna, O. and Shevchenko, M. (2019), Development of data compressing coding methods on basis of binary binomial numbers, Technology Audit and Production Reserves, No. 2/2(46), pp. 12-18. https://doi.org/10.15587/ 23128372.2019.169897.

19. Kulyk, I.A., Novgorodcev, A.I. and Skordina, E.M. (2016), "Binomial'naja model' vektornogo predstavlenija bazy dannyh s kolonochnoj strukturoj" [Binomial model for data base vector representation with columnar structure], Information Processing Systems, No. 4(141), pp. 50-56.

20. Smirnov, M.A. (2004), “Obzor primeneniya metodov bezusherbnogo szhatiya dannyh v SUBD” [Review on application of lossless data compression methods in DBMS], Saint-Petersburg State University of Aerospace Instrumentation, SaintPetersburg, 58 p., available at: www.compression.ru/download/articles/ db/smirnov_2003_database_compression_review.pdf (accessed 04 March 2020).

21. Kulyk, I.A., Skordina, E.M., and Kostel, S.V. (2011), “Generirovanie kodov-sochetanij dlya resheniya informacionnyh zadach IUS" [Generation of code-combinations for solving MIS's information tasks], Automated management systems and automation devices, No. 155, pp. 15-23. 
22. Kulyk, I.A., Novgorodcev, A.I., Skordina, E.M. and Arbuzov, V.V. (2014), “Obobshhennye verojatnosti neobnaruzhivaemoj oshibki dlja kvaziravnovesnyh kodov" [Generalized undetected error expectancy of an quasi-constant weight code], Information Processing Systems, No. 9(125), pp. 43-49.

23. Kulyk, I.A., Skordina, E.M. and Kostel, S.V. (2010), "Formirovanie kvaziravnovesnyh kodov na osnove dvoichnyh binomial'nyh chisel" [Formation of quasi-equilibrium codes on basis of binary binomial numbers], Bulletin of Sumy state university, Series “Tehnichni nauki”, No. 1, Sumy state university, pp. 134-142.

24. Kohzuki K., Tokiwa, K. and Tanaka, H. (1997), A Class of Single Error Correcting Constant Weight Codes, Electronics and Communications in Japan, Part 3, Vol. 80, No. 7, pp. 55-64. https://doi.org/10.1002/(SICI)1520-6440(199707) 80:7<55::AID-ECJC7>3.0.CO;2-0.

25. Kulyk, I.A. (2012), "K voprosu o slozhenii binomial'nyh chisel” [To the problem on addition of binomial numbers], Bulletin of Sumy state university, Series “Tehnichni nauki”, No. 3, Sumy state university, pp. 101-109.

Надійшла до редколегії 16.03.2020

Схвалена до друку 12.05.2020

\section{Відомості про авторів:}

\section{Кулик Ігор Анатолійович}

кандидат технічних наук доцент

Сумського державного університету,

Суми, Україна

https://orcid.org/0000-0003-2403-8671

\section{Information about the authors:}

\section{Igor Kulyk}

Candidate of Technical Sciences Associate Professor

of Sumy State University,

Sumy, Ukraine

https://orcid.org/0000-0003-2403-8671

\author{
Maryna Shevchenko \\ Doctoral Student \\ of Sumy State University, \\ Sumy, Ukraine \\ https://orcid.org/0000-0002-1434-5996
}

\title{
РАЗРАБОТКА ИНФОРМАЦИОННО-УПРАВЛЯЮЩИХ СИСТЕМ НА ОСНОВЕ ДВОИЧНОЙ БИНОМИАЛЬНОЙ СИСТЕМЫ СЧИСЛЕНИЯ
}

\author{
И.А. Кулик, М.С. Шевченко
}

В статье предлагается к рассмотрению концепция разработки информационно-управляющих систем на основе биномиальных систем счисления, в основе которой лежит новая информачионная технология обработки данных на базе биномиальных чисел. В рамках данной технологии производится формирование кодовых объектов биномиальной структуры, их преобразование в двоичные биномиальные числа и обратное преобразование результируюших кодовых объектов в выходные данные на основе двоичной системы счисления. Приведены подходы к решению информачионных задач с использованием биномиальных чисел.

Ключевые слова: производительность, двоччные биномиальные числа, биномиальные преобразования.

\section{DEVELOPMENT OF INFORMATION-MANAGEMENT SYSTEMS ON BASIS OF BINARY BINOMIAL NUMBER SYSTEMS}

\section{Kulyk, M. Shevchenko}

In the paper information-management system development conception on basis of binary binomial number systems is considered. It is based on the new information technology on data processing using binary binomial numbers. There are three interrelated science schools applied in this technology: combinatorial configurations generation on structures of ordered sets of binary binomial numbers, combinatorial configurations enumeration by means of binary binomial number systems and development of machine binomial arithmetic. The constant weight codes, quasi-equilibrium codes and other codes-combinations, which are widely-distributed enough in the information-management systems, are proposed in the capacity of combinatorial configurations. According to the pointed technology code objects of a binomial structure applying to input binary data are generated, then the obtained code objects are converted into binary binomial numbers to carry out standard or specialized information processes, after that the binary binomial numbers or corresponding to them code objects of a binomial structure are converted into output data on basis of binary number systems. The approaches and ideas to put into practice solving of type or specific information problems are given using binary binomial numbers. Application of binary binomial numbers has for an object to increase processing power of information-management systems under minimum additional hardware and software expenses. The adaptive binomial data compression, binomial self-diagnosis and error control, generation of combinatorial configurations and solution of some combinatorial optimization tasks on basis of binomial numbers, the implementation of binomial arithmetic are under review as illustrations in the paper.

Keywords: processing power, binary binomial numbers, binomial conversions, binomial number systems. 